DOI: $10.19195 / 0137-1134.107 .9$

\author{
KRYSTYNA KOWALIK-BAŃCZYK
}

Institute of Law Studies, Polish Academy of Sciences

\title{
THE RULE OF LAW IN THE EUROPEAN UNION - IS THERE A COMMON DEFINITION?
}

\section{INTRODUCTION}

The conditionality of acceptance of the rule of law by the Member States of the European Union admitted to it since 2004 has been compared to the situation of Ulysses. The newly democratized countries of the Central and Eastern Europe agreed to be bound by various international obligations - stemming both from EU law as well as from the acquis of the Council of Europe - in order not to relinquish into a possibly seductive memories of the past, where such a democratic order was not in place. This comparison was recently very strongly exploited by Jan Werner Müller, who was mainly describing the situation in Hungary and Romania ${ }^{1}$. As he wrote:

the region's government sought to lock themselves into Europe precisely so as to prevent from "backsliding"; it was like Ulysses letting himself be bound to the mast in order to resist the siren songs of illiberal and antidemocratic voices in the future ${ }^{2}$.

He raised that neither Viktor Orbán nor Victor Ponta were right to accuse Brussels of some form of Euro-colonialism - as the EU is only ,reminding them how they wanted to live once they were joining the Union"3.

The comparison to Ulysses and the question of what might constitute sirens' singing appeared recently also in the Polish context ${ }^{4}$, with the first case of launching the "rule of law" procedure against one of the Member States of the European

${ }^{1}$ In case of Romania, referring to the 2012 crisis over the powers of the Constitutional Court.

2 J.-W. Müller, "Should the EU Protect Democracy and the Rule of Law inside Member States?", European Law Journal 2015, no. 2, p. 146; citing: J. Elster, Ulysses and the Sirens: Studies in Rationality and Irrationality, Cambridge 1979.

3 J.-W. Müller, op. cit., p. 147.

4 Professor Ewa Łętowska also made a comparison to Ulysses, stating that the Constitution constitutes a set of bounds for a nation in case this nation "falls into craziness", cf. E. Łętowska in an interview with R. Woś, "Jak się dogadać", Polityka, no. 12 (3051) of 16 March 2016. Cf. also A. von 
Union by the European Commission ${ }^{5}$. The argument of the rule of law is used to underline Polish international obligations (on the basis of the Treaty on the European Union). One can wonder whether such a legal bound not to relinquish into memories of the past or illusions of populism and demagogy is to be identified. This brings about a broader question of what is actually understood by the rule of law within the European Union and what the ways of addressing the "rule of law" crisis by the EU institutions and its Member States are. One can wonder whether the EU is equipped to defend the rule of law in Member States and whether such an external intervention is legitimate ${ }^{6}$. Some explanations are provided in the European Commission Communication on a new EU Framework to strengthen the Rule of Law (hereinafter Communication on Rule of Law) ${ }^{7}$. One also has to refer to the recent examples of presumed infringements on the rule of law in various Member States to understand the gradual response to this problem. It might be perceived as a reaction to a broader problem of the lack of reaction on the part of one of the Member States (Hungary) to the opinions of the Venice Commission ${ }^{8}$

Bogdandy, How to Protect European Values in the Polish Constitutional Crisis, Verfassungsblog, 31 March 2016.

${ }^{5}$ Cf. launching of the Rule of Law Procedure on 13th of January 2016 by the European Commission. Cf. also the Opinion on amendments to the Act of 25 June 2015 on the Constitutional Tribunal of Poland, adopted by the Venice Commission at its 106th Plenary Session (Venice, 11-12 March 2016), CDL-D (2016) 001.

6 The ambitions of the European Commission in the rule of law procedure has been assessed by the Council as a „power grab" - cf. Council of the European Union, Opinion of the Legal Service 10296/14, 14 May 2014, cited by D. Kochenov, L. Pech, "Upholding the Rule of Law in the EU: On the Commission's 'Pre-Article 7 Procedure' as a Timid Step in the Right Direction”, EUI Working Papers, RSCAS 2015/24 Robert Schuman Centre for Advanced Studies Global Governance Programme-164, available at: http://cadmus.eui.eu/bitstream/handle/1814/35437/RSCAS_2015_24. pdf? sequence $=3$ (24 June 2016), p. 9. But, as nicely put by those authors, the situation of trying to legitimate the European Commission's actions would be very difficult as "by avoiding Treaty change, the Commission sensibly avoided a situation akin to asking turkeys to vote for Christmas", p. 10.

${ }^{7}$ Communication from the Commission to the European Parliament and the Council. A new EU Framework to strengthen the Rule of Law, Brussels, 19.3.2014, COM(2014) 158 final/2. Cf. comment on this document: D. Kochenov and L. Pech, op. cit.

8 Cf. the Opinions of the European Commission for Democracy Through Law (the Venice Commission) on Hungary since 2011: 1) CDL-AD(2011)016 Opinion on the new Constitution of Hungary adopted by the Venice Commission at its 87th Plenary Session (Venice, 17-18 June 2011); 2) CDL-AD(2011)001 Opinion on three legal questions arising in the process of drafting the New Constitution of Hungary - Adopted by the Venice Commission at its 86th Plenary Session (Venice, 25-26 March 2011); 3) CDL-AD(2012)001 Opinion on Act CLXII of 2011 on the Legal Status and Remuneration of Judges and Act CLXI of 2011 on the Organisation and Administration of Courts of Hungary, adopted by the Venice Commission at its 90th Plenary Session (Venice, 16-17 March 2012); 4) CDL-AD(2012)009 Opinion on Act CLI of 2011 on the Constitutional Court of Hungary adopted by the Venice Commission at its 91st Plenary Session (Venice, 15-16 June 2012); 5) CDL$\mathrm{AD}(2012) 020$ Opinion on the Cardinal Acts on the Judiciary that were amended following the adoption of Opinion CDL-AD(2012)001 on Hungary, adopted by the Venice Commission at its 92nd Plenary Session (Venice, 12-13 October 2012); 6) CDL-AD(2012)004 Opinion on Act CCVI of 2011 
and multiple political actions of EU institutions, in particular the so-called Tavares report of European Parliament ${ }^{9}$.

\section{NOW, WHAT IS THE RULE OF LAW IN THE EUROPEAN UNION?}

The concept of the "country of law" stems from the 19th-century legal and political tradition of Rechtstaat ${ }^{10}$. In the British system, this notion corresponds to the rule of law principle ${ }^{11}$. The concept of the country of law is based on the idea that we are dealing with a democratic country ${ }^{12}$, which implies respect for certain standards of behaviors both between the different organs of state system (based on checks and balances) and between state organs and individuals (citizens). The idea of the rule of law implies that noblesse oblige - a country that is to be perceived as a rule of law country has to respect human rights and guarantee a system of efficient remedies in case those rights are breached ${ }^{13}$.

on the right to freedom of conscience and religion and the legal status of churches, denominations and religious communities of Hungary adopted by the Venice Commission at its 90th Plenary Session (Venice, 16-17 March 2012); 7) CDL-AD(2012)012 Joint Opinion on the Act on the Elections of Members of Parliament of Hungary adopted by the Council for Democratic Elections at its 41st meeting (Venice, 14 June 2012) and the Venice Commission at its 91st Plenary Session (Venice, 15-16 June 2012); 8) CDL-AD(2012)023 Public Opinion on Act CXII of 2011 on informational Self-determination and Freedom of Information of Hungary, adopted by the Venice Commission at its 92nd Plenary Session (Venice, 12-13 October 2012); 9) CDL-AD(2013)012 Public Opinion on the Fourth Amendment to the Fundamental Law of Hungary Adopted by the Venice Commission at its 95th Plenary Session, Venice, 14-15 June 2013; 10) CDL-AD(2015)015 Public Opinion on Media Legislation (ACT CLXXXV on Media Services and on the Mass Media, Act CIV on the Freedom of the Press, and the Legislation on Taxation of Advertisement Revenues of Mass Media) of Hungary, adopted by the Venice Commission at its 103rd Plenary Session (Venice, 19-20 June 2015).

9 Report of 25 June 2013 on the situation of fundamental rights: standards and practices in Hungary (pursuant to the European Parliament resolution of 16 February 2012) (2012/2130(INI)). Committee on Civil Liberties, Justice and Home Affaires. Rapporteur: Rui Tavares.

10 M. Verdussen, "La signification du principe de l'Etat de droit pour l'administration en Europe", [in:] H. Bauer, C. Calliess (eds.), Verfassungsprinzipien in Europe. Constitutional Principles in Europe. Principes Constitutionnels en Europe, Athens-Berlin-Brussels 2008, pp. 190-191, who states: "Etat de droit c'est l'état de la Constitution". As a central feature of the country of law, this author takes "la centralité de l'individu".

11 Z. Kmieciak, Postępowanie administracyjne w świetle standardów europejskich, Warszawa 1997, pp. 30-31.

${ }_{12}$ A democratic country is a country based on "pluralism, tolerance and the spirit of openness", ECtHR 7 December 1976, app. No 5493/72 Handyside v United Kingdom; J. Andriantsimbazovina, De la difficulté de construire un ius commune européen des droits de l'homme. Quelques considérations sur la jurisprudence de la Cour européenne des droits de l'homme en 2004, CDE 2006, p. 246.

13 Very clearly expressed in: The Rule of Law Checklist, Venice Commission of the Council of Europe, adopted by the Venice Commission at its 106th Plenary Session (Venice, 11-12 March 2016), p. 13. Cf also the Council of Europe Commissioner for Human Rights Nils Muižnieks, Report on 
The concept of the rule of law comes down to the idea that law is the basic element of relations between an individual and a country, which means that the state organs do not overstep/trespass its competences and powers and always act in a mitigated way while intervening in the social life ${ }^{14}$ (accordingly to the idea of proportionality).

\section{ARTICLE 2 TEU AND THE RULE OF LAW IN THE EUROPEAN UNION}

\section{Article 2 of the Treaty on the European Union states:}

The Union is founded on the values of respect for human dignity, freedom, democracy, equality, the rule of law and respect for human rights, including the rights of persons belonging to minorities. These values are common to the Member States in a society in which pluralism, non-discrimination, tolerance, justice, solidarity and equality between women and men prevail.

The values mentioned in Article 2 TUE have not been created by the Treaty, they are pre-existing principles that form part of the European heritage (also mentioned in the preamble to the Treaty) ${ }^{15}$.

According to the European Commission, the rule of law is "based on the common constitutional traditions of the Member States and the case law of the CJEU". The Commission understands the rule of law as covering: legality understood as a transparent, accountable, democratic and pluralistic process for enacting laws; legal certainty, prohibition of arbitrariness of the executive powers, independent and impartial courts, effective judicial review including respect for fundamental rights and equality before the law $^{16}$. The Venice Commission of the Council of Europe develops much more on the constituting elements of the rule of law compliance ${ }^{17}$.

Poland, 2016, http://www.coe.int/en/web/commissioner/-/erosion-of-rule-of-law-threatens-humanrights-protection-in-poland (24 June 2016).

14 M. Wyrzykowski, "Legislacja — demokratyczne państwo prawa — radykalne reformy polityczne i gospodarcze”, Państwo i Prawo, 1991, fsc. 5, p. 18; cf. also W. Taras, A. Wróbel, Zarys koncepcji państwa prawnego w praktyce RPO, Warszawa 1991, p. 40; E.H. Morawska, Klauzula państwa prawnego w Konstytucji RP na tle orzecznictwa Trybunalu Konstytucyjnego, Torun 2003.

15 R. Geiger, “Commentary to art. 2 TUE”, [in:] R. Geiger, D.-E. Khan, M. Kotzur (eds.), European Union Treaties. Treaty on European Union, Treaty on the Functioning of the European Union, Oxford 2015, p. 15. This author states that the principle of the rule of law contains different expressions: lawfulness of public administration, legal security, legal certainty, protection of legitimate expectations, non-retroactive effect of penal laws, principle of proportionality (pp. 15-16).

16 E.-M. Poptcheva, Understanding the EU Rule of Law Mechanisms, European Parliament Research Service, PE 573.922. p. 6.

17 The Rule of Law Checklist, Venice Commission of the Council of Europe, adopted by the Venice Commission at its 106th Plenary Session (Venice, 11-12 March 2016), pp. 17-49. 
The rule of law is mainly exercised by courts - as they are the ones able to verify whether the actions undertaken by different state organs are in accordance with the legal rules and legal reasoning. Therefore, the broad interpretation of the rule of law was confirmed by the jurisprudence of the Court of Justice, cited in the Communication on the Rule of Law. In case 294/83 Les Verts, where a political group was searching for a declaration that two decisions of the Bureau of the European Parliament concerning the allocation of budget resources were void, the CJEU stated, referring itself to the principle of legality, that

the European Economic Community is a Community based on the rule of law, inasmuch as neither its Member States nor its institutions can avoid a review of the question whether the measures adopted by them are in conformity with the basic constitutional charter, the Treaty ${ }^{18}$.

In case C-496/99 P Commission v CAS Succhi di Frutta, concerning the legality of the Commission decision amending the conditions of the invitation to tender after awarding the contract, the CJEU clearly stated that in case of an error committed by the European Commission, this organ is to either restore the original situation or make suitable amendments in the future to the system applied by ${ }{ }^{11}{ }^{19}$. In joint cases 46/87 and 227/88 Hoechst $v$ Commission, the CJEU stated that

in all the legal systems of the Member States, any intervention by the public authorities in the sphere of private activities of any person, whether natural or legal, must have a legal basis and be justified on the grounds laid down by law, and, consequently, those systems provide, albeit in different forms, protection against arbitrary or disproportionate intervention. The need for such protection must be recognized as a general principle of Community law ${ }^{20}$.

In case C-583/11 P Inuit Tapiriit Kanatami and Others $v$ Parliament and Council, on the action for annulment of the regulation imposing restrictions on importing and marketing seal products, the CJEU again confirmed that "the European Union is a union based on the rule of law in which the acts of its institutions are subject to review of their compatibility with, in particular, the Treaties, the general principles of law and fundamental rights" 21 . All those cases, cited by the European Commission in its Communication on the rule of law, are in a sense "internal", referring to the functioning of the European Union institutions and their relationship with EU citizens.

18 Judgment of the Court of Justice of 23 April 1986 in case 294/83 Parti écologiste "Les Verts" $v$ European Parliament, ECLI:EU:C:1986:166, para 23.

19 Judgment of the Court of Justice of 29 April 2004 in case C-496/99 P Commission of the European Communities v CAS Succhi di Frutta SpA, ECLI:EU:C:2004:236, para 63.

20 Judgment of the Court of Justice of 21 September 1989 in case 46/87 Hoechst AG v Commission of the European Communities, ECLI:EU:C:1989:337, para 19.

21 Judgment of the Court of Justice of 3 October 2013 in case C-583/11 P Inuit Tapiriit Kanatami and Others $v$ European Parliament and Council of the European Union, ECLI:EU:C:2013:625, para 91. 
The provision of Article 2 TEU with its direct confirmation that the rule of law applies in the EU, was not always present in the EU legal order. It was only the perspective of Eastern enlargement in the 1990s that led the EU to introduce first the Copenhagen criteria as a political agreement ${ }^{22}$, whose fulfilment was a precondition for accession; and then as an element of primary law in the Treaty of Amsterdam ${ }^{23}$. It can be argued, as done by Wojciech Sadurski, that the EU accession was for the new Member States a shield for democracy that would protect those countries from losing their democratic character ${ }^{24}$. It was believed that the accession might help to consolidate i.a. the rule of law, also because this "external" element might help the process of modernization led from outside, as the Poles did not fully believe it was possible on the basis of internal capabilities only ${ }^{25}$. But on the other hand, there is no single model of democracy in the EU countries, which is confirmed by the principle of protection of national identity, introduced by the Treaty of Lisbon ${ }^{26}$.

The principle of the rule of law, next to the principle of democracy, can be perceived as a "foundational constitutional principle" from which all other principles and rules emanate ${ }^{27}$. Usually, for the law of the European Union, it was used as a guideline for the actions of the EU itself, as it seemed that at the national level the obligation to obey the law is obvious and does not need an express confirmation ${ }^{28}$. It means that all organs of the Union must act within substantive limits and conform with procedural requirements. It goes straight to the principle of legality the organs of power must act under and within the law. They must act within their powers, which excludes any actions ultra vires. Because of this, there were authors who interpreted that Article 2 concerned the European Union as such and that this provision imposed an obligation on the EU to keep the principle of the rule of law in its relationships among the institutions and individuals, with full respect for the principle of proportionality (Art. $5.3 \mathrm{TEU})^{29}$. It means that the same standards as

22 It refers to the 1993 summit of the European Council in Copenhagen, where the Member States agreed to enlarge the EU if the candidate countries fulfil the so-called Copenhagen criteria: respect for human rights, democracy and the rule of law.

${ }^{23}$ W. Sadurski, "Adding Bite to a Bark: The Story of Article 7, EU Enlargment, and Jörg Heider", Columbia Journal of European Law 16, Summer 2010, no. 3, p. 387.

24 W. Sadurski, Constitutionalism and the Enlargement of Europe, Oxford 2012, p. 143.

25 Ibid., p. 144.

26 Ibid., p. 152.

27 H.C.H. Hofmann, G.C. Rowe, A.H. Türk, Administrative Law and the Policy of the European Union, Oxford 2011, p. 145.

28 Ibid., pp. 148-149. Cf. case 294/83 Les Verts v Parliament [1986] ECR 1339, para 23. Also: J.J. Jacqué, “Article 2 TUE”, [in:] H. von der Groeben, J. Schwarze, A. Hatje (eds.), Europäisches Unionsrecht, Baden Baden 2015, p. 67.

29 D. Miąsik, "Komentarz do art. 5 ust. 3 TWE", [in:] A. Wróbel (ed.), Traktat ustanawiajacy Wspólnotę Europejską. Komentarz, Warszawa 2008, p. 206. 
at the national level should be applied at the EU level ${ }^{30}$. This opinion is not to be kept in light of the recent developments (the issuing of the Rule of Law Procedure Communication in 2014 by the European Commission and its further use).

\section{THE IDEA OF UNIVERSALISM VERSUS THE IDEA OF PARTICULARITY OF THE RULE OF LAW}

It seems obvious and the Treaty on European Union clearly states that the values enlisted in Art. 2 TEU, including the rule of law - are common to the Member States. The very language of Art. 2 speaks of com mon values. However, we do have also a shared legal order of the EU and its Member States ${ }^{31}$. They mutually respect each other and are supposed to cooperate loyally in terms of Art. 5.3 TEU. Thus, despite the fact that there is no common blueprint as to what the rule of law means - the conditionality of accession was based on the idea of having some minimal treshholds - certain minimal conditions to be fulfilled in order to be let $i^{32}$. After the fall of the Communist rule, the countries of Central and Eastern Europe have made a transformation into democratic states often by repeating the Western templates of democratic institutions ${ }^{33}$. But even with the common values, the Member States enjoy their constitutional autonomy (in the language of Constitutional courts of EU Member States) or national identity (in the language of Art. 4.2 TEU) ${ }^{34}$. Article 4.2 TEU requires that the European Union shall

respect the national identities of Member States, inherent in their fundamental structures, political and constitutional, inclusive of regional and local self-government. It shall respect their essential State functions, including ensuring the territorial integrity of the State, maintaining law and order and safeguarding national security.

30 W. Sawczyn, "Sąd administracyjny jako gwarant ochrony praw strony postępowania w przedmiocie wymierzania kar administracyjnych", [in:] M. Stahl, R. Lewicka, M. Lewicki (eds.), Sankcje administracyjne. Blaski i cienie, Warszawa 2011, p. 647, this author is of the opinion that it is a disregard to the principle of the rule of law to penalize similar behaviours once in administrative law provisions, once in criminal law provisions.

31 A. Gerbrandy, M. Scholten, "Core Values: Tensions and Balances in the EU Shared Legal Order", [in:] T. van den Brink, M. Luchtman, M. Scholten (eds.), Sovereignty in the Shared Legal Order of the EU. Core Values of Regulation and Enforcement, Intersentia-Cambridge-Antwerp, 2015 , p. 9.

32 W. Sadurski, Constitutionalism..., p. 153.

33 H.-W. Micklitz, "Prologue: The Westernisation of the East and the Easternisation of the West", [in:] M. Bobek (ed.), Central European Judges Under the European Influence, OxfordPortland, Oregon 2015, p. 5.

34 A. Von Bogdandy, S. Schill, "Overcoming Absolute Primacy: Respect for National Identity under the Lisbon Treaty”, Common Market Law Review 48, 2011, p. 1417. 
Considering this provision, one might wonder whether this obligation also works in case of "constitutional capture", where for instance one of the Member States is trying to dismantle the separation of powers? Is the European Union to desist its concerns if constitutional structures and mechanisms are put in danger, simply out of respect for national identity of a Member State? Or should it, in such circumstances, consider itself responsible for the protection of the rule of law in one of the Member States? It seems that the answer must be positive, implying that the protection of the rule of law is an obligation on the part of the European Union, as if one of the game players ceased to be a democratic country, it might destabilize the whole system and put in question the mutual trust among the Member State $^{35}$. This need of maintaining the mutual trust has been recently confirmed by the CJEU in case C-168/13 Jeremy F v Premier Minister, where the CJEU stated:

[t]he principle of mutual recognition on which the European arrest warrant system is based is itself founded on the mutual confidence between the Member States that their national legal systems are capable of providing equivalent and effective protection of the fundamental rights recognised at European Union level, particularly in the $\mathrm{Charter}^{36}$.

Some authors think that mutual trust can „hardly survive when one national system ceases to be governed by the rule of law ${ }^{37}$.

\section{THE POSSIBLE CASES OF A NEED FOR PROTECTION OF COMMON VALUES FROM ART. 2 TEU BY THE EUROPEAN UNION}

Article 7 TEU, broadly considered below, provides the procedures of reaction to the infringement of common values. Those procedures have never been used directly. But there has been some situations, in which their use has been considered. The first such case concerned Austria in $2000^{38}$. The EU leaders did not use Art. 7 TEU but resorted to fourteen bilateral coordinated moves of the EU governments to sanction Austria's coalition government, including Haider's party: 1) suspension of contacts with Austrian government officials, 2) the withdrawal of EU support for Austrian application for senior positions in international organizations, 3) absence of contacts with Austrian ambassadors. In 2012 Romania underwent a crisis over the enactment of the Constitutional Tribunal rulings, as the then Prime Minister

35 T. Wischmeyer, "Generating Trust Through Law? Judicial Cooperation in the European Union and the "Principle of Mutual Trust", German Law Journal. 17, 2016, no. 3, p. 339.

36 Judgment of the Court of 30 May 2013 in case C-168/13 PPU Jeremy F. v Premier minister, ECLI:EU:C:2013:358, para 50; by analogy cf. judgment of the Court of Justice of 22 December 2010 in case C491/10 PPU Joseba Andoni Aguirre Zarraga v Simone Pelz, ECLI:EU:C:2010:828, paras 70 and 71 .

37 D. Kochenov, L. Pech, op. cit., p. 5.

38 W. Sadurski, "Adding a Bite..." 
was not satisfied with their contents and refused to publish them ${ }^{39}$. But the country that has so far raised the biggest concern regarding the protection of the rule of law within the EU remains Hungary. After the 2010 elections, Viktor Orbán's party Fidesz introduced a new Constitution (2011) which in the common opinion dismantled checks and balances. This raised the question of wether the EU is equipped to defend democracy and the rule of law in its Member States. Since 2011 till present there has been a confirmed (by the opinions of the Venice Commission) continuing constitutional capture in the Republic of Hungary. In 2011, when the new Hungarian Constitution was adopted, the first opinion of the Venice Commission was issued ${ }^{40}$. It concerned the situation of adopting the constitution within 35 days on the basis of the text that has not been consulted (the one that has been consulted with the society was not taken into account). Further threats to the rule of law consisted in the practice of issuing cardinal laws instead of normal laws,

39 CDL-AD(2012)026 Public Opinion on the compatibility with Constitutional principles and the Rule of Law of actions taken by the Government and the Parliament of Romania in respect of other State institutions and on the Government emergency ordinance on amendment to the Law $\mathrm{N}^{\circ} 47 / 1992$ regarding the organisation and functioning of the Constitutional Court and on the Government emergency ordinance on amending and completing the Law $N^{\circ} 3 / 2000$ regarding the organisation of a referendum of Romania, adopted by the Venice Commission at its 93rd Plenary Session (Venice, 14-15 December 2012).

$40 \mathrm{Cf}$. the Opinions of the European Commission for Democracy Through Law (Venice Commission) on Hungary since 2011: 1) CDL-AD(2011)016 Opinion on the new Constitution of Hungary adopted by the Venice Commission at its 87th Plenary Session (Venice, 17-18 June 2011); 2) CDL$\mathrm{AD}(2011) 001$ Opinion on three legal questions arising in the process of drafting the New Constitution of Hungary - adopted by the Venice Commission at its 86th Plenary Session (Venice, 25-26 March 2011); 3) CDL-AD(2012)001 Opinion on Act CLXII of 2011 on the Legal Status and Remuneration of Judges and Act CLXI of 2011 on the Organisation and Administration of Courts of Hungary, adopted by the Venice Commission at its 90th Plenary Session (Venice, 16-17 March 2012); 4) CDLAD(2012)009 Opinion on Act CLI of 2011 on the Constitutional Court of Hungary adopted by the Venice Commission at its 91st Plenary Session (Venice, 15-16 June 2012); 5) CDL-AD(2012)020 Opinion on the Cardinal Acts on the Judiciary that were amended following the adoption of Opinion CDL-AD(2012)001 on Hungary, adopted by the Venice Commission at its 92nd Plenary Session (Venice, 12-13 October 2012); 6) CDL-AD(2012)004 Opinion on Act CCVI of 2011 on the right to freedom of conscience and religion and the legal status of churches, denominations and religious communities of Hungary adopted by the Venice Commission at its 90th Plenary Session (Venice, 16-17 March 2012); 7) CDL-AD(2012)012 Joint Opinion on the Act on the Elections of Members of Parliament of Hungary adopted by the Council for Democratic Elections at its 41st meeting (Venice, 14 June 2012) and the Venice Commission at its 91st Plenary Session (Venice, 15-16 June 2012); 8) CDL-AD(2012)023 - Public Opinion on Act CXII of 2011 on informational Self-determination and Freedom of Information of Hungary, adopted by the Venice Commission at its 92nd Plenary Session (Venice, 12-13 October 2012); 9) CDL-AD(2013)012 Public Opinion on the Fourth Amendment to the Fundamental Law of Hungary, adopted by the Venice Commission at its 95th Plenary Session, (Venice, 14-15 June 2013); 10) CDL-AD(2015)015 Public Opinion on Media Legislation (ACT CLXXXV on Media Services and on the Mass Media, Act CIV on the Freedom of the Press, and the Legislation on Taxation of Advertisement Revenues of Mass Media) of Hungary, adopted by the Venice Commission at its 103rd Plenary Session (Venice, 19-20 June 2015). 
which allowed for avoiding the social consultation process (49 cardinal laws were adopted during 18 months). In addition, there occurred a constant use of accelerated legislative procedures with no participation of civil society, which restricted the public debate. The Venice Commission was also concerned with the restrictions of independence of the judiciary. First, this guarantee disappeared from the new Constitution. Second, the mandate of the President of Supreme Court was ended before its term (two years instead of six) ${ }^{41}$. The procedural changes introduced to the functioning of the Constitutional Court were judged by the Venice Commission as hampering the effectiveness of this Court by rendering decision-making extremely difficult. Further concerns concentrated on the reform of election system, by which the citizens of Hungary were obliged to first register, in order to be able to vote in parliamentary elections. Further, the media law reform was considered problematic, because no independence was guaranteed to the Media Authority and there was a growing intransparency in granting licenses for media activities. Last but not least, the freedom of religion was said to be limited in Hungary, as more than 300 registered churches lost their status, since in order to continue their activity they were obliged to be recognized by the Parliament of Hungary.

The strongest EU response to those developments consisted in the Tavares report 2013, adopted by the European Parliament in July 2013. This document envisaged the creation of the so-called "Copenhagen Commission" that would review the continued compliance with the Copenhagen criteria used for admission to the EU on the part of any Member State. It indirectly also led to the adoption of the Communication on the rule of law of 2014.

In Poland the idea of the rule of law has appeared on the scene recently in the context of the dispute over the appointment of judges of the Constitutional Tribunal. The weakening of the Constitutional Court might lead to weakening of the main check of executive and legislative power, which might be harmful to democracy as $\operatorname{such}^{42}$. Constitutional courts prevent democratic self-destruction — such non-elected institutions not only defend individuals, but the democracy as a whole ${ }^{43}$. The Polish constitutional crisis turned out to be a struggle over influence (wrongly perceived, as in fact there should be no "our" and "their" judges ${ }^{44}$ ) but also an attempt to paralyze the Constitutional Tribunal altogether ${ }^{45}$. As Anna Śledzińska-Simon puts it, in the Polish constitutional crisis the biggest

41 ECtHR 23 June 2016 Baka v Hungary, app. No. 20261/12.

42 J.-W. Müller, "Should the EU Protect Democracy and the Rule of Law Inside Member States?", European Law Journal 21, 2015, no. 2, p. 154.

43 Ibid., p. 152.

44 A. Śledzińska-Simon, Midnight Judges: Poland's Constitutional Tribunal Caught between Political Fronts, Verfassungsblog, 23 November 2015.

45 Together with other radical changes subordinating the domains of power to the present political majority: media, civil service, public prosecution, communication data. A. Śledzińska-Simon, Paradoxes of Constitutionalisation: Lessons from Poland, Verfassungsblog, 30 March 2016. 
paradox is that "both sides waive the flag of the rule of law" but the interpretation is very different ${ }^{46}$.

\section{INSTRUMENTS OF ACTION FOR THE PROTECTION OF THE RULE OF LAW}

The values enlisted in Article 2 TEU are protected in double speed. First, they form part of the so-called Copenhagen criteria, verified for the countries that are candidates for EU membership. Respect for such values is a precondition for entry to the EU. Second, after accession, the Member States must observe and promote EU values, as otherwise they might face the mechanism enshrined in Art. 7 TEU, containing a procedure to sanction a Member State that does not uphold those values.

In order to use Art. $7 \mathrm{TEU}$, there are two steps to be taken (some authors think that they are not interdependent) ${ }^{47}$. First, on a reasoned proposal by one third of the Member States, by the European Parliament or by the European Commission, the Council, acting by a majority of four fifths of its members after obtaining the consent of the European Parliament may determine that there is a clear risk of a serious breach by a Member State of the values referred to in Article 2 TEU. Before the Council determines this situation of clear risk of a serious breach, it should hear the Member State concerned and address to it its recommendations. Only as a second step, the European Council, acting by unanimity, may determine the existence of a serious and persistent breach by a Member State of the values referred to in Article 2, after inviting the Member State in question to submit its observations. After this determination, the Council, acting by a qualified majority, may decide to suspend certain rights deriving from the application of the Treaties for the Member State in question. At the same time the obligations of that Member State under the Treaties should continue to be binding on that State. If Article 7 TEU is used, the CJEU has a very limited role to play: according to Article 296 TFEU it can be called to review the procedural requirements stipulated in Article 7 TEU and this can be done only by the Member State concerned.

In recent years, as described above, there have occurred first reflections on how to use Art. 7 TEU. But this provision, called at a certain point by Manuel Barosso a "nuclear option" 48 , is first of all very difficult to be used and second - it is perceived as perhaps too detrimental to the whole EU system, which in fact might

\footnotetext{
46 Ibid.

47 D. Kochenov, L. Pech, op. cit.

48 As cited by Ibid, p. 2.
} 
mean it is unusable ${ }^{49}$. Therefore some other means of reacting to the infringement on the rule of law by one of the Member States might also be considered.

The second possibility of reacting consists in infringement proceedings led by the European Commission. This solution is not really adapted to the fight specific political challenges to liberal democracy. The cases so far decided by the CJEU have not proved to be really efficiently improving the situation in Hungary ${ }^{50}$. There have been two cases under Art. 258 TFEU where the European Commission was questioning some infringements of the EU law. In case C-286/12 Commission $v_{\text {Hungary }}^{51}$ the Commission alleged violation of independence of the judiciary caused by the provision in the Transitional Act (supplement to the Constitution). By lowering the retirement age of judges from 70 to 62 years, which, as a consequence, led to retirement of 274 judges and public prosecutors in a very short time, the Hungary was found to have infringed the EU law. Those who retired were mainly the court's presidents who assign cases. The Commission used only Directive $2000 / 78$ on equal treatment in employment and not any general provisions referring to common values of the European Union. Despite this judgment most of the judges concerned never returned to the previously held positions ${ }^{52}$.

The second case C-288/12 European Commission v Hungary ${ }^{53}$ covered the situation where the Freedom of Information Act removed the Parliamentary Commissioner for Data Protection and established a new governmental agency, the National Agency for Data Protection lacking a degree of independence required by Directive 95/46. This independence was also violated by forced resignation of the former Data Protection Officer before the end of his term. Similarly in this case, the person concerned (the Commissioner) was not reestablished, despite the fact that the infringement was stated.

Those proceedings failed to address broader institutional issues that threaten the rule of law and liberal democracy ${ }^{54}$. Therefore Jan Werner Müller proposed to introduce a system of gradated sanctions that might end up with expulsion

49 W. Sadurski, "Adding a Bite..."

50 C-288/12 Commission v Hungary, C-286/12 European Commission v Hungary. Cf. A. von Bogdandy et al., "A European Response to Domestic Constitutional Crisis: Advancing the ReverseSolange Doctrine", [in:] A. von Bogdandy, P. Sonnevend (eds.), Constitutional Crisis in the European Constitutional Area. Theory, Law and Politics in Hungary and Romania, Oxford-Portland, Oregon 2015, p. 235.

51 Judgment of the Court of 6 November 2012 in case C-286/12 European Commission v Hungary, ECLI:EU:C:2012:687.

52 K. Scheppele, "Making Infringement Procedures More Effective”, EUTopia Law, 29 April 2014, available at: eutopialaw.com (24 June 2016).

53 Judgment of the Court of Justice of 8 April 2014 in case C-288/12 European Commission v Hungary, ECLI:EU:C:2014:237.

54 B. Bugarič, "Protecting Democracy and the Rule of Law in the European Union: The Hungarian Challenge”, LSE' Europe in Question' Discussion Paper Series, LEQS Paper, no. 79/2014, July 2014, p. 20. 
of a Member State from the $\mathrm{EU}^{55}$. The gradated sanctions could consist in cutting EU cohesion funds or imposing significant fines.

The same author also proposed to create something called the Copenhagen commission - following the suggestions in the Tavares report ${ }^{56}$. According to this author, a body that would verify the Copenhagen criteria in a following manner: 1) no pre-emptive actions, but just the verification of a track record of violating liberal-democratic political principles; 2) such violations have to be of a systemic nature; 3) intervention should be about enforcing commitments that were entered into voluntarily in the past ${ }^{57}$. This idea has not been upheld for the time being, but the ideas of the form of dialogue led were repeated by the European Commission in its Communication on the rule of law.

Some other authors propose to react to the constitutional crisis in a particular Member State by a strong reaction of national courts through application of the so-called reversed Solange doctrin $\mathrm{e}^{58}$. It would consist in claiming European fundamental rights in the individual national legal actions ${ }^{59}$, as a completing element to the political solutions existing parallelly.

To have a full picture one has to take into account also the reactions of EU institutions to the opinions of the Venice Commission (formally called: the European Commission for Democracy through Law ${ }^{60}$ ) regarding the situation in Hungary and Romania since $2010^{61}$. The main reaction were the infringement proceedings instituted by the European Commission against Hungary (C-286/12 and C-462/12); suspension of some economic commitments to Hungary from the EU Cohesion Fund and a lot of statements and opinions in the human rights area, with the main example of a resolution issued by the European Parliament on 3 July $2013^{62}$.

All those instruments did not prove to be very helpful in cases of constitutional capture in the Member States. Therefore, in March 2014 the European Commission issued a communication about a new framework for protecting the rule of law within the EU Member States. This newly adopted document featured

55 J.W. Müller, "Safeguarding Democracy Inside the EU: Brussels and the Future of Liberal Order", Transatlantic Academy Working Paper, p. 23.

56 Report of 25 June 2013 on the situation of fundamental rights: standards and practices in Hungary (pursuant to the European Parliament resolution of 16 February 2012, 2012/2130 (INI), available at: http://www.europarl.europa.eu/sides/getDoc.do?pubRef=-//EP//TEXT+REPORT+A72013-0229+0+DOC+XML+V0//EN.

57 J.-W. Müller, op. cit., pp. 155-156.

58 A. von Bogdandy et al., "Reverse Solange — Protecting the Essence of Fundamental Rights against EU Member States", Common Market Law Review 49, 2012, p. 516.

59 A. von Bogdandy et al., op. cit., pp. 235-236.

60 Existing since 1992. At present 47 member states of the Council of Europe are members of the Venice Commission, as well as 12 states that are not members of the Council of Europe.

61 J. Nergelius, "The Role of the Venice Commission in Maintaining the Rule of Law in Hungary and in Romania”, [in:] Constitutional Crisis in the European Constitutional Area ..., p. 291.

62 Described in: Ibid., pp. 306-307. 
a structured dialogue between the Commission and the Member State in question. The Communication on the rule of law suggests the possibility of taking three steps in case of a possible rule of law infringement in one of the Member States. First, an assessment of the situation in a particular country, which can result in a "rule of law opinion" naming the concerns of the Commission towards the national government. Second, if the government fails to respond, the Commission can issue a "rule of law recommendation". Third, if the country fails to respond, the Commission might proceed to use the mechanisms set out in Article 7 TEU.

The European Commission would engage in this type of structural dialogue with a Member State concerned only in cases where the threats to the rule of law are systemic in nature (according to the definition of such threats adopted in the jurisprudence of the $\mathrm{CJEU}^{63}$ ). The Commission gives three criteria that should be fulfilled in order to see such a threat: (1) the measures or situations are likely to systematically and adversely affect, (2) the integrity, stability or the proper functionning of the institutions and the safeguard mechanisms (3) established at national level to secure the rule of law'.

On 13 January 2016 the Commission decided for the first time to initiate such an assessment of the situation for Poland with regard to two Polish laws - on the powers of the Constitutional Court and on the management of state TV and radio broadcasters. The first step of the rule of law procedure, consisting in issuing an opinion on the situation in Poland was taken in June 2016.

\section{CONCLUSIONS — LEGITIMACY OF EXTERNAL INTERVENTION}

Considering the analysis conducted in this article, there should be no doubt that the European Union should play a role in protecting liberal democracy in its Member States in the situation of "constitutional capture"64. Still, this type of intervention should be led in a very prudent way, in order not to provoke a nationalist backlash. If the EU takes a "punitive" approach, as advocated by some Commissioners - things might get worse and inhibit the process of democracy ${ }^{65}$. One should remember, however, that the traditional patterns of loyalty, referring to the national level, have lost their shape, as the "local" matters became by definition the "European" matters ${ }^{66}$. The danger of overplaying the punitive approach

63 Judgment of the Court of Justice of 21 December 2011 in case C-411/10 N.S. v Secretary of State for the Home Department and C-493/10 M. E. and Others v Refugee Applications Commissioner and Minister for Justice, Equality and Law Reform, ECLI:EU:C:2011:865; judgment of the Court of Justice of 14 November 2013 in case C-4/11 Bundesrepublik Deutschland v Kaveh Puid, ECLI:EU:C:2013:740.

64 J.-W. Müller, "Should the EU Protect Democracy...,", pp. 141-160.

65 Argumentation for Hungary: B. Bugarič, op. cit., p. 3.

66 W. Sadurski, Constitutionalism ..., p. 203. 
is unfortunately strengthened by the conditionality argument. As Bojan Bugarič states: "the irony of that conditionality [of Copenhagen criteria], so powerful before the CEE countries joined the EU, loses much of its teeth once countries become member states of the EU"67. So the potential solution of a constitutional crisis depends very much on the good will of the parties involved. Regardless of using the noblesse oblige argument - if you entered this organization, you should know how to behave - there is a strong need of a mutual understanding that both sides need to play by the legal rules for their own (very realistically taken ${ }^{68}$ ) sake.

\section{PAŃSTWO PRAWA W UNII EUROPEJSKIEJ - CZY ISTNIEJE WSPÓLNA DEFINICJA?}

\section{Streszczenie}

Tematem opracowania jest problematyka ochrony zasady państwa prawa w prawie Unii Europejskiej. Przedstawione zostały zarówno rozważania teoretyczne nad samym pojęciem zasady państwa prawa w Unii Europejskiej, jak i aktualne tendencje, by do tej zasady sięgać w związku z rozwojem sytuacji politycznej w niektórych państwach członkowskich UE.

67 B. Bugarič, op. cit.

68 Especially after the Brexit referendum of 23 June 2016. 